\begin{tabular}{ll}
\hline \hline MINING AND METALLURGY INSTITUTE BOR & ISSN: 2334-8836 \\
& UDK: 622 \\
\hline \hline
\end{tabular}

UDK: $338.1: 622(045)=20$

DOI:10.5937/MMEB1303033N

Radmilo Nikolić, Nenad Vušović, Igor Svrkota ${ }^{*}$, Branislav Mihajlovic ${ }^{* * *}$

\title{
POSITION OF SERBIAN COPPER PRODUCTION COMPLEX ON THE WORLD MARKET
}

\begin{abstract}
This paper presents the status, importance and role of copper in development the modern world economy. The main features of the world copper market are analyzed, such as: trends in consumptioncumulative and per capita, trends in production, exploitation reserves of copper - cumulative and by exploitation period, and finally the impact of new mining projects to projection of balance and imbalance of supply and demand on the world copper market. An analysis of the Serbian copper complex position on the world market is presented, along with comparison of copper resources between Serbia and the world. Also, the cost curve and position of the Serbian copper production complex are present$e d$, accompanied by analysis of influencing factors that define the position of the Serbian copper production on the global market, as well as comparison with copper mining and processing companies in the world. Finally, a suggestion for possible routes of strategic activities is introduced, aiming to improve the existing position of the Serbian copper production on global market.
\end{abstract}

Keywords: market, strategy, copper, trends, reserves, resources

\section{INTRODUCTION}

Copper production has a long history in Serbia. Excavation and processing of copper ore has lasted continuously for more than a century. Copper production complex went through different periods during that time, but it has always had very strong influence to industrial development in various social and political circumstances. In general, it could be said that copper production in Serbia had a constant growth till 70's of the last century. Then in 80's and 90's, there was stagnation, and finally a massive fall down in the first decade of this century. However, in the last couple of years, the Serbian Government took over the authority on copper production and started the process of reconstruction, modernization and stabilization of production facilities. In 2010, this program was started to apply through the massive technological and organizational improvements followed by huge investments. Due to the importance and influence of this program to entire Serbian development, this paper evaluates the current position of Serbian copper production complex on the world market and provides the projection of this position in the future based on current program.

\section{IMPORTANCE OF COPPER FOR GLOBAL INDUSTRIAL DEVELOPMENT}

The oldest objects made of copper come from $6,000 \mathrm{BC}$. The usage of copper for primitive tools and weapons is characteristic for entire epoch in the human history, known as the Copper Age. Also, in the next

\footnotetext{
* University of Belgrade, Technical Faculty in Bor

** $R T B-R B B$ Bor
} 
epoch, known as the Bronze Age, copper was an important factor since bronze is an alloy of copper and tin. The oldest known copper mines were situated in Sinai desert, Cyprus (that is why Latin name for copper was cuprum) and also Rudna Glava near Bor, eastern Serbia.
The New Age with its rapid scientific and industrial development brought a significant need for copper. Inventions of dynamo (1870) and AC motor (1887) started the era of electrical engineering, which made copper one of the most important and needed metals, up to the present day.

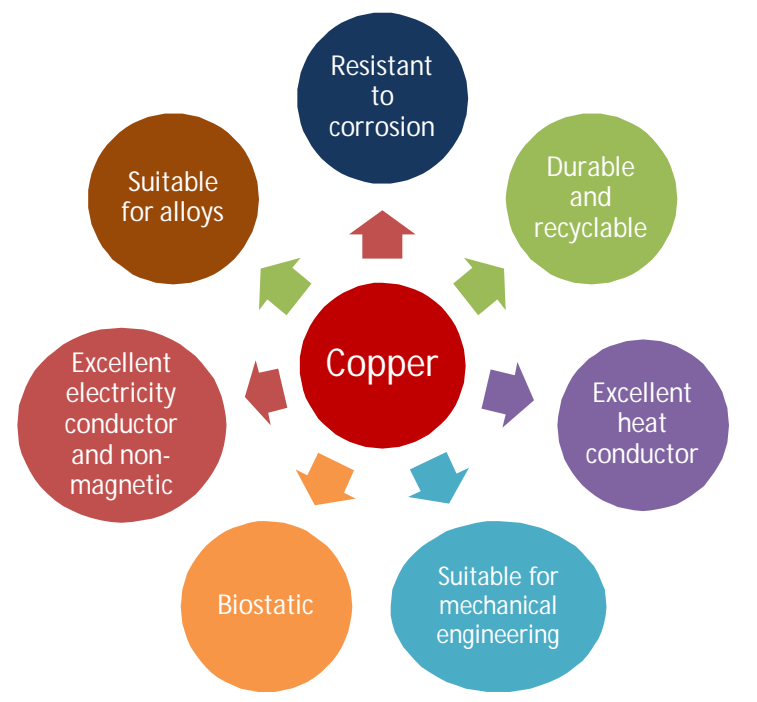

Figure 1 Review of the most imortant properties of copper [1]

Beside excellent electrical conductivity, copper has many other useful properties that make it very important ad irreplaceable in modern global industry. Figure 1 shows its main properties that make copper so usable.

\section{WORLD COPPER MARKET}

\section{Trends of Consumption - Cumulative and per Capita}

The twentieth century brought a huge development and expansion of industrial production. At the beginning of century, there was a global redistribution of power, which meant that big colonial forces were not the most powerful countries anymore; the new leaders were countries with the best developed capitalism of that time, such the US and Germany.

That was the period of strong industrial development which caused the urge for raw material. Copper production growth curve is almost exponential. At the beginning of $20^{\text {th }}$ century, the global copper consumption was slightly below one million tons per year (Figure 2), while at the end of the century, it was almost twenty times higher. Such growth trend continued in the $21^{\text {st }}$ century too, and in 2011 it almost reached $20 \mathrm{Mt}$ per year, or per capita - $3 \mathrm{~kg} /$ year 


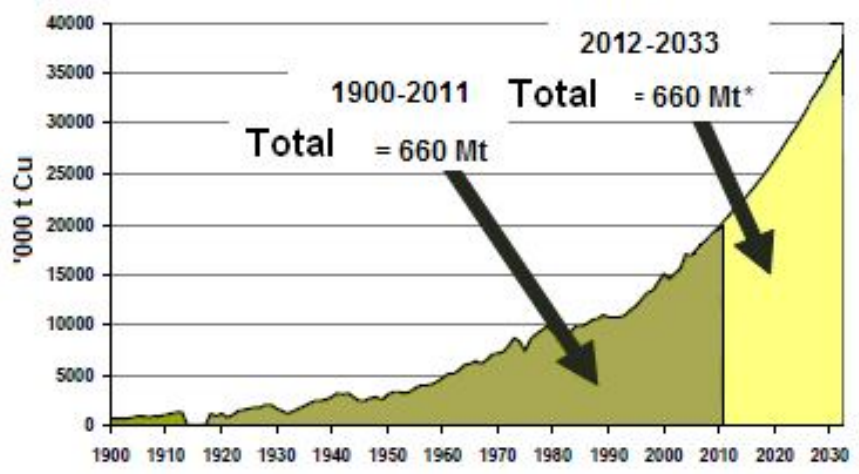

${ }^{\text {A }}$ For predicted annual global growth rate of $3 \%$ Source: CRU, BHP Billiton

Figure 2 Global copper consumption (cumulative) and projection till 2033 [2]

\section{Trends of Production}

Copper production has very important position in the global industrial growth. Global need for raw material rises rapidly from the beginning of last century, especially for nonferrous metals and copper, as the most important of them. Such trend has even been boosted in the last decade, due to the industrial expansion of China, some Far East countries and BRICS countries.

Even with such growth trend, copper production managed to follow it. However, the projections of further growth lead to concerns about possible misbalance between the exponential consumption growth and limited production possibilities. The fact is that trends of global industrial and population growth superimpose, which would make an additional impact to demands on copper in the future. Figure 2 shows that predicted copper consumption in the next 22 years will almost match total consumption in the entire human history till today. The global copper production would not be able to follow such trends.

\section{Exploitable Copper Reserves - Quantitative and per Years}

Along with expansion of copper production, the copper ore reserves became exhausted. Such situation forced the new exploration works in order to find the new ore deposits. The main trend in properties of new deposits was a decrease of ore grades and an increase of deposit depths.

As a consequence, same amount of metal production required excessive mining and mineral processing works. Copper production industry had to follow the requirements regardless on circumstances, which meant that production costs had to be reduced. That was accomplished through the increase of productivity, technological innovations and organizational improvements.

As the result of intense exploration works, the global copper ore reserves had a constant increase. However, copper production also increased, which meant that in any moment the existing copper ore reserves provided 30 to 50 years of production. The current reserves reach 630 Mt of copper, which would be sufficient, according to the predictions, for the next 30 years. 


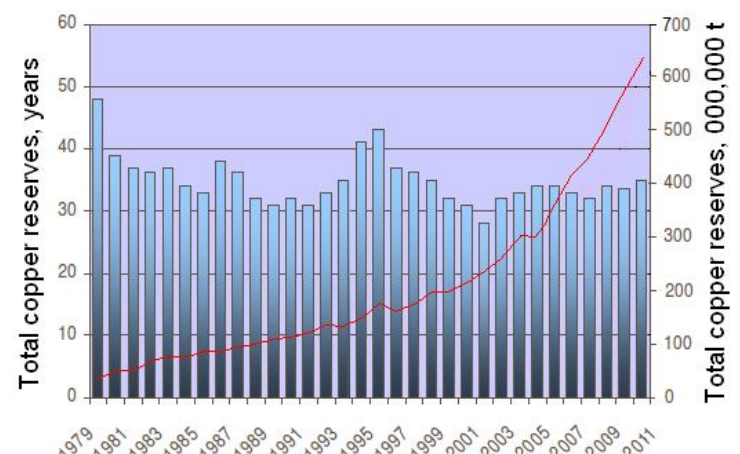

Figure 3 Exploitable copper reserves - quantitative and per years [4]

\section{New Projects - Balance and Misbalance of Supply and Demand}

The global level of mining and mineral processing output slightly exceeds $16 \mathrm{Mt}$ of copper in 2011. Analysis of market flow shows that production will be able to match the demands for several more years, but then it will start to lag behind. Figure 4 shows that already in 2018 misbalance of supply and demand would reach $5 \mathrm{Mt}$ of copper and $6 \mathrm{Mt}$ in 2020. This means that the gap would have to be closed by the new copper mines, thus providing the global output increase of $1 \mathrm{Mt}$ of copper annual rate.

The new projects and new mines are developed in unfavorable circumstances, because ore grades are reduced and amount of overburden is grown. This causes the in crease of costs. Currently, majority of new mines are opened in deposits with 0.5 to $0.6 \%$ of $\mathrm{Cu}$, with average cost price of 6,000 US\$/t. There is also a trend of increase by products share in total income.

One of the consequences of aggravation in basic copper production is a compromise between political and geological risks. It means that copper production will move to the developing countries, with higher business risk, more and more in the future. Another one is a compromise between capital and operational costs. It means that decreasing quality of available resources causes abandoning of principles like "high capital investments require low operational costs".

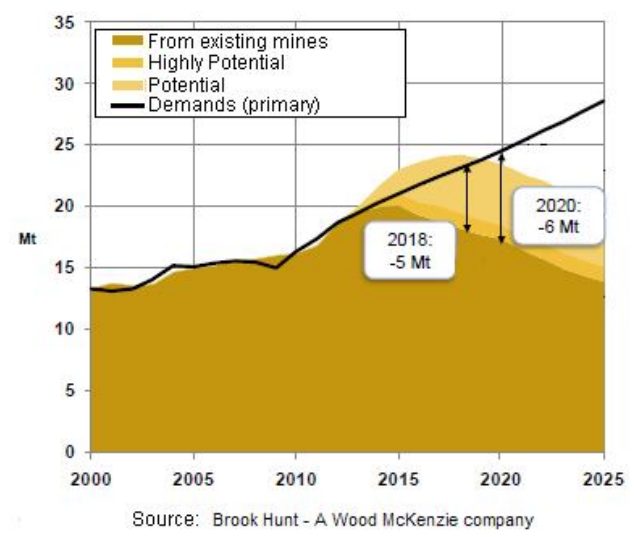

Figure 4 Trend of global copper mining production [2] 
That is why there are the intense global activities in developing new projects for mining and mineral processing of copper ores. In total, there are some 7,000 of projects in progress. A distribution of projects by ten most important countries is given in Figure 5. It should be added that only several percent of total number of projects will be completely realized.

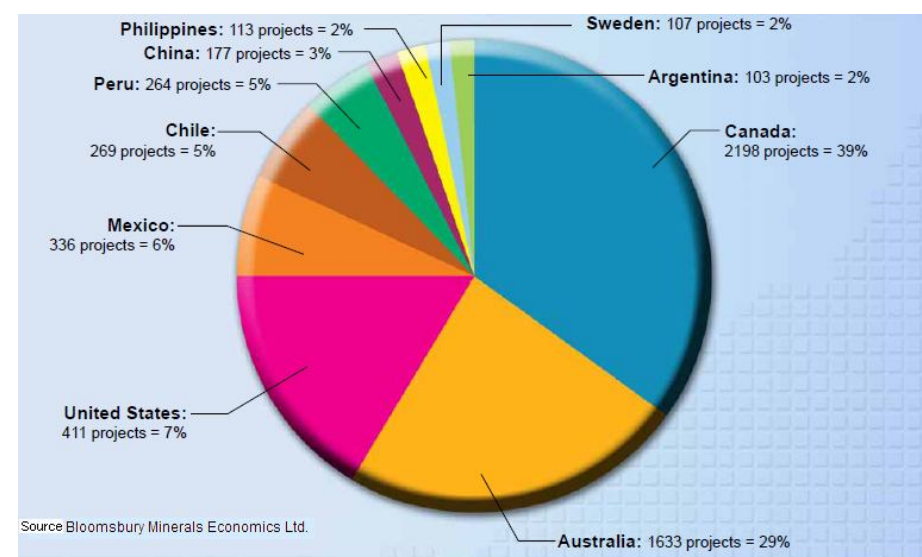

Figure 5 Schedule of projects for exploitation and primary processing of copper in the top ten countries in the world [5]

\section{Long - term Predictions on position of copper at the world market}

The expected increase of demand of copper on the world market reaches $10 \mathrm{Mt}$ in the next $10-15$ years (Figure 4). The estimations of leading analysts say that the existing level of reserves should be enough for that period. Some analysts even predict slight excess of supplies in the middle of decade. This situation is explained by increased utilization of scrap (recycled copper).

General assessments of leading analysts say that the predicted cost price of 6,000 US\$/t (2.77 US\$/lb) in next decade should be sufficient (and necessary) to match increasing market demands and consumption trends mentioned earlier. The lowest cost price in the new projects is $3,000 \mathrm{US} \$ / \mathrm{t}$, the highest is $8,000 \mathrm{US} \$ / \mathrm{t}$, while $6,000 \mathrm{US} \$ / \mathrm{t}$ price meets $75 \%$ the future requirements.

It should be also kept in mind that increase of production costs is structural, with the following key components:

- Geographical factors - manpower,

- Geological factors-exhaustion of existing ore deposits, and
- Increasing energy crisis.

Increased industrialization of developing countries will increase the demands on copper on the world market, regardless to the prediction of substitution growth on some markets in the first part of decade.

Prediction of average direct production costs is $0.94 \mathrm{US} \$ / \mathrm{lb}$, while intensity of capital investment is $12,000 \mathrm{US} \$ / \mathrm{t}$ (total investments / average annual output).

Projected Mean IRR (Internal Rate of Return) is $15 \%$.

Analyses of sensibility of predicted cost price (2.77 US $\$ / \mathrm{lb})$ show its high sensitivity to the market expectations of mining companies. Level of capital costs is also a key factor for the project economics. As it was mentioned before, their mean level is 12,000 US $\$ / t$, but globally it varies from 6,000 US $\$ / t$ (for high - graded deposits) to 22,000 US\$ (for huge porphyry low - graded deposits).

If the global trends of copper consumption growth are compared with the global GDP growth, it can be concluded that this 
relation was approximately 0.6 till 90 's, then it reached 1.03 between 1990 and 2000, and it stabilized at 0.64 afterwards.

The estimations say that approximately $20 \%$ of the global copper consumption should be covered by recycling in the future. The share of recycled copper will vary from $14 \%$ to $21 \%$ and it would be dependable on absolute values of prices of copper and scrap on the market, as well as their relative relation.

\section{POSITION OF THE SERBIAN COPPER PRODUCTION COMPLEX ON THE WORLD MARKET}

Serbia has a long term history of existence on the global copper market. As it was mentioned before, until 70's the position of Serbia was very important, with $2 \%$ share of global production. Serbian copper resources were well known by their ore grades and participation of precious metals. Serbian copper production complex was globally highly appreciated at that time.

The end of golden era of Serbian copper production came with decrease of ore grades in ore deposits, increasing depths of ore deposits and many other factors, such as increase of waste in copper mining and falling of prices on the world market. All these factors had a negative influence to the business economy.

\section{Comparison of Serbian and Global Mining and Mineral Processing Resources}

After nearly 80 years of copper production in mainly comfortable circumstances, the ore grades started to reduce rapidly. At the end of 70's, content of copper in the ore has fallen down below $1 \%$ and such trend is a constant. Currently, the excavated ore has 0.25 to $0.28 \%$ of copper, while projections for the next decade predict $0.33 \% \mathrm{Cu}$ as the mean value. It was mentioned before that the global trend for new projects is approximately 0.5 to $0.6 \%$ of $\mathrm{Cu}$, which means that the quality of Serbian resources planned for next decade is twice lower than global resources. The mean ore grades in Serbian copper mining are shown in Figure 6.

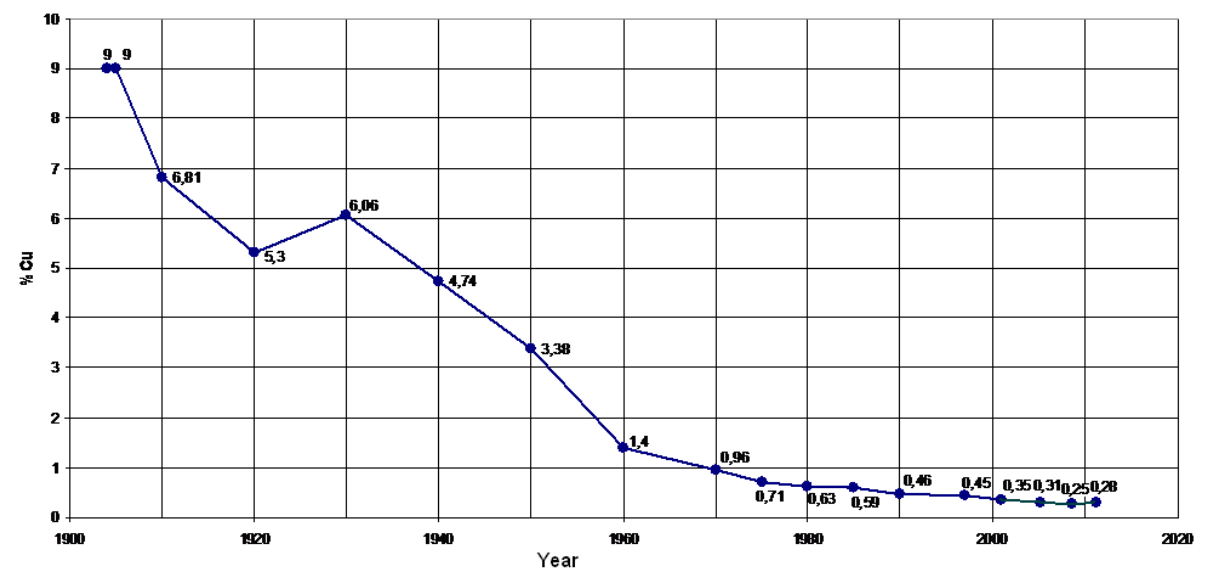

Figure 6 Mean ore grades in the Serbian copper mining [10]

When the new copper mines are designed, usual amount is 400 to $800 \mathrm{t}$ of excavated bulk material for $1 \mathrm{t}$ of copper. In Serbia, it exceeds 1,000 t. If the amount of excavations per ton of produced copper is compared in the world and in Serbia, based on projections for the next decade, it can be concluded that the Serbian copper produc 


\section{Cost Price Curve and Position of Serbian Copper Production Complex in it}

tion would require 2.5 times more excavations than others. Consequently, this means that the ore reserves included in the Serbian projections of copper mining in the next ten years will not be able to provide a competitive position of Serbian copper production on the world market.

While there are the new projects and mine designs with projected $6,000 \mathrm{US} \$ / \mathrm{t}$ cost price around the world, at the same time the Serbian estimations of cost price reach $8,000 \mathrm{US} \$ / \mathrm{t}$. This is a serious risk in terms of future existence the Serbian copper production complex on the world market.
If mining company wants to survive on the world market (and provide profitability), it needs to place itself and be competitive with the other mining companies. Price of metal on the world market is not valid for evaluation the company competitiveness.

Price of metal is unstable and mainly out of the producer control. However, the costs are controllable. Position on the cost price curve defines the competitiveness and business risks for any company, which means that efforts have to be made in order to cut the costs. Cost price curve for 2011 is shown in Figure 7.

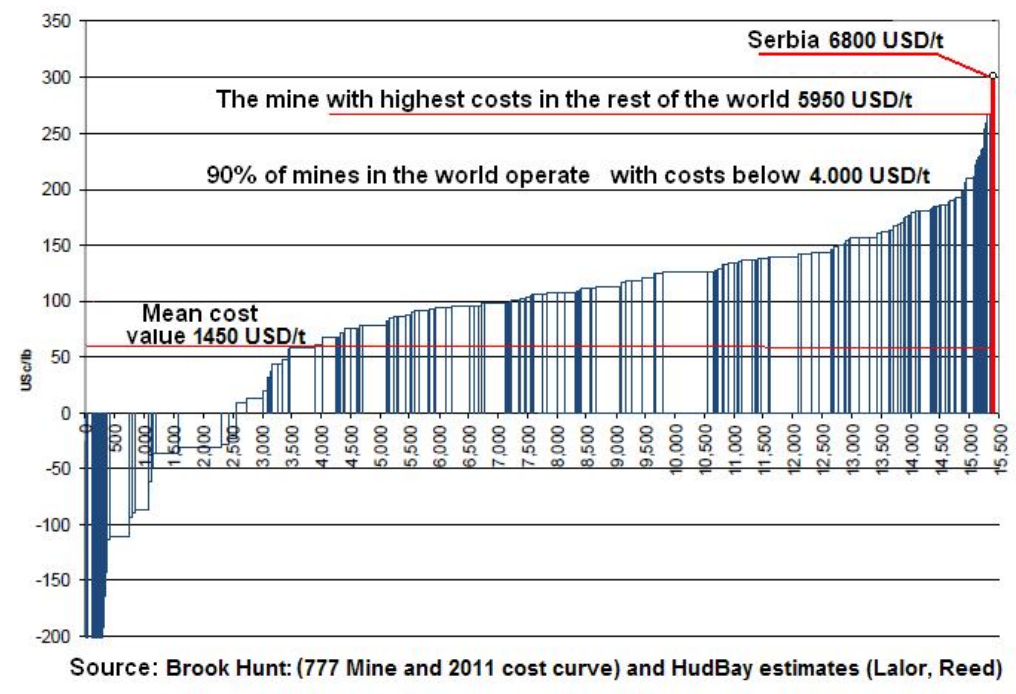

Figure 7 Position of the Serbian copper production complex in the global cost curve [3]

The main strategy or long term projection for each mine ore mining company is to provide a good position on the cost curve. The aim is to reach lower left part of curve. Figure 7 shows that position of Serbia is at the right end, with costs reaching 6,800 US\$/t, which is extremely uncompetitive. Figure 7 also shows that $17 \%$ of the global copper production comes as a byproduct, where the main product is usually gold, that the mean cost value is $1,450 \mathrm{US} \$ \mathrm{t}$ and $90 \%$ of companies in the world produce copper with the cost price lower than 4,000 US\$/t. The highest recorded cost price in the world, apart from Serbia, is $5,950 \mathrm{US} \$ / \mathrm{t}$. 


\section{CONCLUSION}

Problems that the Serbian copper production complex has had to deal with for a long time are the poor quality of ore reserves, increasing depth of ore deposits and bulk of excavations needed to produce a ton of copper. That is why its competitiveness on the world market is poor. In order to improve such position, it is necessary to raise the quality of ore reserves and reduce bulk of excavations. This is possible to achieve through the intense exploration works, in order to discover the new deposits and also through including some existing ore deposits into programs of strategic development. The Borska Reka is an example of ore body whose properties are more favorable than properties of the currently active ore deposits.

There are some other issues to be solved, too. The most important are determination of permanent company status, definition of internal organization model and financial stability. Defining of these strategic issues, along with the improved production management, technological discipline and more rational business decisions should enable profitable production and long - term sustainable development and finally more competitive position on the world market.

\section{REFERENCES}

[1] AQM Copper Inc, Copper fundamentals, 2010.

[2] Boliden Group, Update and Market Outlook, CMD 2011.

[3] Brook Hunt, 777 Mine and 2011 Cost Curve, 2011.

[4] Indian Bureau of Mines, Market Survey on Copper, Ngapur, 2011.

[5] Interra Resource Intelligence, Copper The New Fundamentals, Mineral Exploration Roundup, 2011.

[6] Mihajlović, B., Exploration of Possibilities for Economic Underground Mining of Existing Ore Reserves. PhD Thesis, Bor, 2003 (In Serbian).

[7] Operative Production Documentation of RTB Bor Group (In Serbian).

[8] Page, C., Steffen, O., Adding Shareholder Value By Strategic Mine Planning, SRK, October, 1998.

[9] Rio Tinto, Exploration and Acquisition in the Global Mining Industry, World Mining Investment Congress, London, 2010.

[10] Stamenković, Đ., Copper From Bor, Past - Present - Future, Bor 1997 (In Serbian). 


\begin{tabular}{ll}
\hline \hline INSTITUT ZA RUDARSTVO I METALURGIJU BOR & ISSN: 2334-8836 \\
& UDK: 622 \\
\hline \hline
\end{tabular}

Radmilo Nikolić, Nenad Vušović, Igor Svrkota ${ }^{*}$, Branislav Mihajlović ${ }^{\text {*** }}$

\title{
POLOŽAJ SRPSKOG KOMPLEKSA PROIZVODNJE BAKRA NA SVETSKOM TRŽIŠTU
}

\begin{abstract}
Izvod
U radu je dat komparativni prikaz položaja, značaja i uloge bakra u razvoju moderne svetske privrede i u Srbiji. Analizirane su glavne karakteristike svetskog tržišta bakra: trendovi potrošnje kumulativni i po stanovniku, trendovi proizvodnje, eksploatacione rezerve bakra-kumulativne i po veku trajanja, kao i uticaj novih rudarskih projekata na projekciju balansa, odnosno debalansa ponude $i$ tražnje bakra na svetskom tržištu. Izvršena je analiza i dat je prikaz položaja kompleksa proizvodnje bakra Republike Srbije na svetskom tržištu, zatim upoređenje resursa Srbije sa resursima bakra u svetu. Dat je prikaz krive cene koštanja i položaj kompleksa proizvodnje bakra u Srbiji na njoj, izvršena analiza uticajnih faktora koji definišu položaj Srpskog kompleksa proizvodnje bakra na svetskom tržištu kao i upoređenje sa kompanijama za otkopavanje i preradu bakra u svetu. Na kraju je dat predlog mogućih pravaca strateških aktivnosti usmerenih na popravljanje postojećeg položaja kompleksa proizvodnje bakra Republike Srbije na svetskom tržištu bakra.
\end{abstract}

Ključne reči: tržište, strategija, bakar, trendovi, rezerve, resursi.

\section{UVOD}

Proizvodnja bakra u Srbiji ima dugogodišnju istoriju. Eksploatacija i prerada ruda bakra kontinuirano se vrše već više od sto godina. $\mathrm{U}$ tom periodu kompleks proizvodnje bakra je prolazio kroz različite periode $i$ imao je snažan uticaj na impozantan privredni razvoj koji se odvijao u vrlo burnim društveno - socijalnim okolnostima. Generalno gledajući, do kraja sedamdesetih godina prošlog veka može se oceniti da je proizvodnja bakra u Srbiji imala rast, osamdesetih i devedesetih godina je došlo do stagnacije, dok je tokom prve decenije dvadeset prvog veka došlo do značajnog pada proizvodnje i urušavanja nekada moćnog sistema za proizvodnju i preradu bakra. Početkom druge decenije ovog veka, odnosno u poslednjih nekoliko godina, Republika Srbija je preuzela nadležnost nad proizvodnjom bakra i započela program rekonstrukcije, modernizacije i stabilizacije njenih proizvodnih kapaciteta. Taj program je 2010. god. započeo da se konkretizuje kroz jedan sveobuhvatan tehnološki i organizacioni zahvat, uz vrlo obiman nivo investicija. Zbog značaja i uticaja pomenutog programa na ukupan razvoj Republike Srbije u celini, u radu je data stručna ocena sadašnjeg položaja kompleksa proizvodnje bakra na svetskom tržištu, kao i projekcija budućeg položaja u skladu sa navedenim razvojnim programom.

\footnotetext{
*Univerzitet u Beogradu, Tehnički fakultet u Boru

** $R T B-R B B$ Bor
} 


\section{ULOGA BAKRA U RAZVOJU MODERNE SVETSKE PRIVREDE}

Najstariji nađeni predmeti od bakra datiraju iz vremena oko 6.000 godina pre Nove ere. Njegova primena za izradu primitivnih alata $\mathrm{i}$ oružja karakteriše čitavu jednu epohu u razvoju čovečanstva, poznatu kao bakarno doba. I u sledećoj epohi, bronzanom dobu, koje je nastupilo oko 3.000 godina Nove ere, bitan činilac je bio bakar, od koga je napravljena tvrda legura bronza. U bronzanom dobu je potpuno istis-

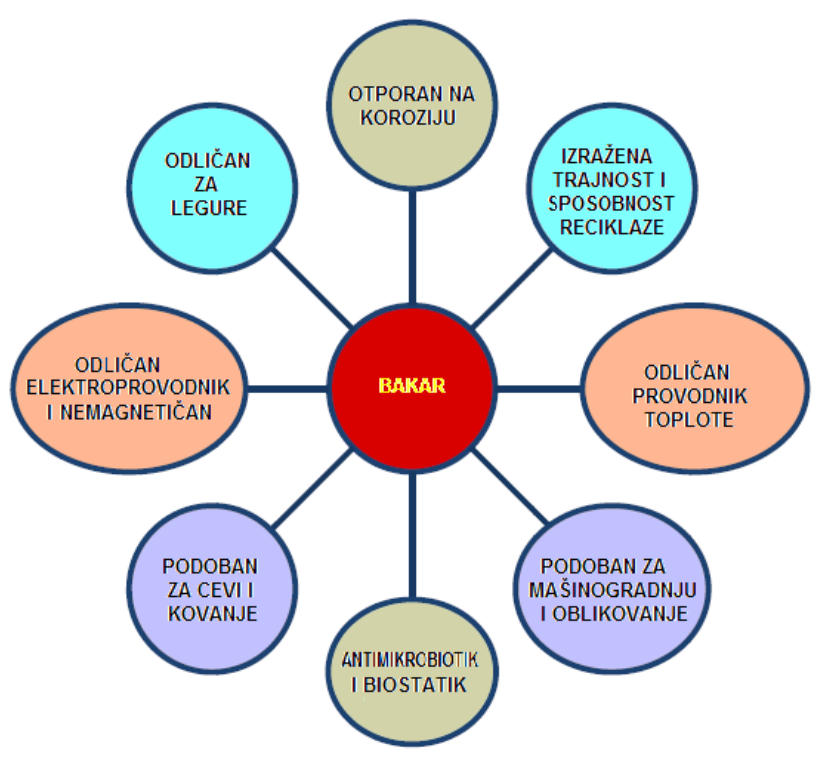

SI. 1. Pregled najvažnijih osobina bakra [4]

nuta upotreba kamenih alatki, a smatra se da je ovo doba završeno tek u Srednjem veku. Najstariji rudnici bakra su u to vreme bili u Sinajskoj pustinji, zatim na Kipru, odakle potiče i latinski naziv bakra - cuprum. Među najstarije rudnike bakra spada i Rudna Glava u okolini Bora.

Novi vek sa naglim razvojem $u$ nauci i industriji doveo je do velikih potreba za bakrom. Pronalaskom dinamo mašine (1870. god.) i motora naizmenične struje (1887. god.), počela je era elektrotehnike, koja je bakar učinila neophodnim metalom, što traje do današnjih dana.

Osim odlične elektroprovodljivosti, bakar ima još niz drugih korisnih osobina koje ga čine jednim od nezamenljivih metala $u$ modernoj svetskoj industriji. Na Sl. 1 dat je prikaz njegovih glavnih osobina zbog kojih se primenjuje $u$ industriji.

\section{KARAKTERISTIKE SVETSKOG TRŽIŠTA BAKRA}

\section{Trendovi potrošnje - kumulativni i po stanovniku}

Dvadesti vek karakteriše snažan razvoj i ekspanzija industrijske proizvodnje. Globalna preraspodela moći početkom veka se sa nekada moćnih kolonijalnih sila prelila na stranu najsnažnije razvijenih 
kapitalističkih zemalja toga doba, koje su predvodile Sjedinjene Države i Nemačka.

U tom periodu sve snažniji zamah industrijskog razvoja je stvorio glad za sve većim količinama sirovina. Bakar beleži eksponencijalnu krivu rasta potrošnje. Početkom dvadesetog veka svetska potrošnja bakra je bila na nivou nešto manjem od milion tona godišnje (vidi sl. 2), da bi se na njegovom kraju skoro dvadeset puta uvećala. Trend takvog rasta potrošnje se nastavio i u XXI veku, te je na kraju 2011. god. potrošnja dostigla nivo od 20 miliona tona godišnje, što po stanovniku zemlje iznosi približno $3 \mathrm{~kg} / \mathrm{god}$.

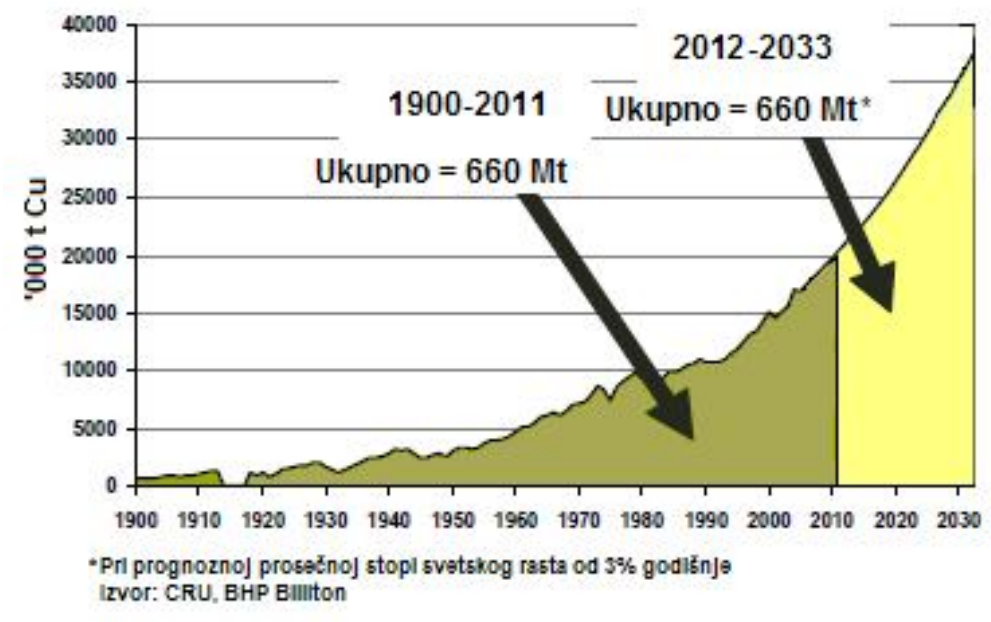

SI. 2. Kumulativna potrošnja bakra u svetu i prognoza do 2033. god. [2]

\section{Trendovi proizvodnje}

Industrija proizvodnje bakra u svetu zauzima visoku stratešku poziciju $u$ ukupnom privrednom rastu. Tokom čitavog prethodnog veka i do današnjih dana u svetu je prisutna velika potreba za sirovinama, a naročito za obojenim metalima, gde bakar zauzima vodeće mesto. Taj trend je $u$ zadnjih desetak godina značajno pojačan eksplozivnom ekspanzijom privrednog razvoja Kine, pojedinih dalekoistočnih zemalja Azije i BRIK-a.

I pored takvog trenda, proizvodnja bakra je uspevala da vrlo uspešno prati eksponencijalni rast potrošnje. Međutim, napred pomenuti eksplozivan rast potrošnje bakra u pojedinim zemljama i prognoze njegovog daljeg rasta, po prvi put su dovele do toga da se već nagoveštava pojava debalansa između eksponencijalno rastuće potrošnje i ogra- ničenih mogućnosti proizvodnje. Naime, trendovi ubrzanog industrijskog rasta i porasta stanovništva u svetu se superponiraju i u budućnosti će još više pojačati pritisak tražnje na tržište bakra. Sa Sl. 2 se može videti da je projekcija potrošnje bakra u svetu takva da se predviđa da se u narednih 22 god. potroši maltene ista količina bakra kao u ukupnoj istoriji čovečanstva do danas. Proizvodnja bakra u svetu te trendove neće moći da prati.

\section{Eksploatacione rezerve bakra - količinski i po godinama}

Paralelno sa ekspanzijom proizvodnje bakra u svetu postojeće rezerve rude su se intenzivno i sve ubrzanije iscrpljivale. To je imperativno nalagalo da se stalno 
istražuju nove rezerve koje bi nadomestile trošenje postojećih. Karakteristika takvog kretanja je bio sve niži kvalitet novih resursa, sa sve nižim sadržajima korisnih komponenti i na sve većim dubinama.

Takav trend je neminovno nametao potrebu da se za istu količinu metala otkopava i prerađuje sve veća količina iskopina. Industrija proizvodnje i prerade bakra je u tim okolnostima morala da stalno traži rešenja kojima bi parirala takvom trendu, odnosno morala je da stalno snižava jedinične troškove proizvodnje, kroz dizanje produktivnosti, tehnološke inovacije i organizaciona poboljšanja.

Kao rezultat intenzivnih geoloških radova na istraživanju, svetske rezerve bakra su se stalno povećavale, ali je njihov vek trajanja održavan na nivou od 30 do 50 godina. Trenutne eksploatacione rezerve iznose oko 630 miliona tona metala, što prema projekcijama rasta predstavlja rezerve za narednih tridesetak godina (vidi sl. 3).

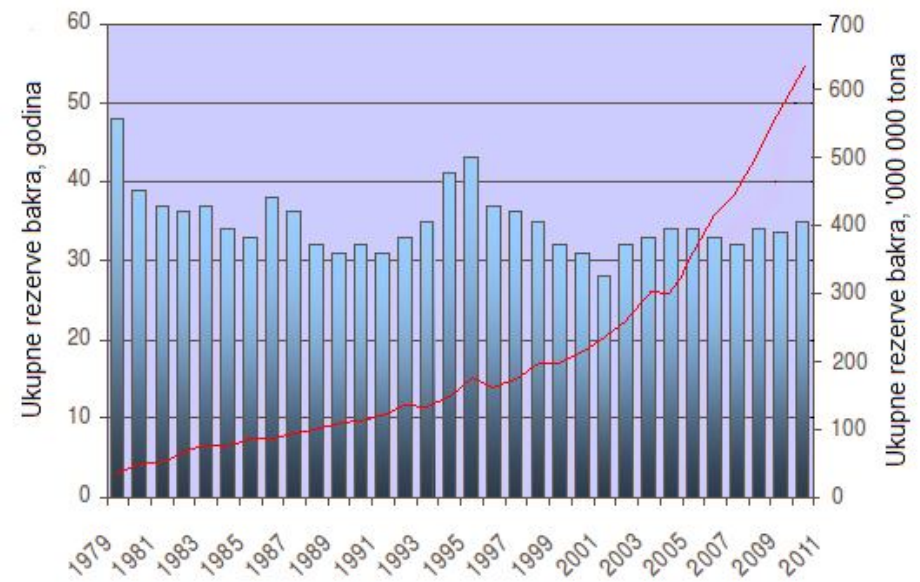

SI. 3. Ukupne rezerve bakra u svetu, količinski i po veku trajanja [9]

\section{Novi projekti - balans/debalans ponude i tražnje}

Trenutni nivo rudničke proizvodnje i primarne prerade bakra u svetu iznosi nešto manje od 17 miliona tona godišnje. Analiza kretanja na svetskom tržištu pokazuje da će još nekoliko godina proizvodnja bakra iz postojećih rudnika moći da prati trend potrošnje, a onda će doći do njenog zaostajanja. Sa sl. 4 se vidi da će već 2018. godine debalans ponude i tražnje biti 5 miliona tona bakra, a 2020. godine biće 6 miliona tona. To praktično znači da će uključivanjem novih rudnika $\mathrm{u}$ proces proizvodnje $\mathrm{u}$ tom periodu morati da se popunjava kapacitet proizvodnje po dinamici od oko 1 milion tona bakra godišnje.

Razvoj novih projekata se odvija u uslovima sve manjeg sadržaja bakra i korisnih metala u rudi, sa sve većom količinom iskopina po toni dobijenog bakra. To podiže cenu koštanja proizvodnje bakra u takvim rudnicima. Trenutno $\mathrm{u}$ svetu novi rudarski projekti se rade sa prosečnim sadržajem bakra od 0.5 do $0.6 \%$ i sa prosečnom cenom koštanja od 5.500 USD/t. Pritom planirani prihodi od nus-proizvoda postaju sve uticajniji na ukupnu ekonomiku projekata. 


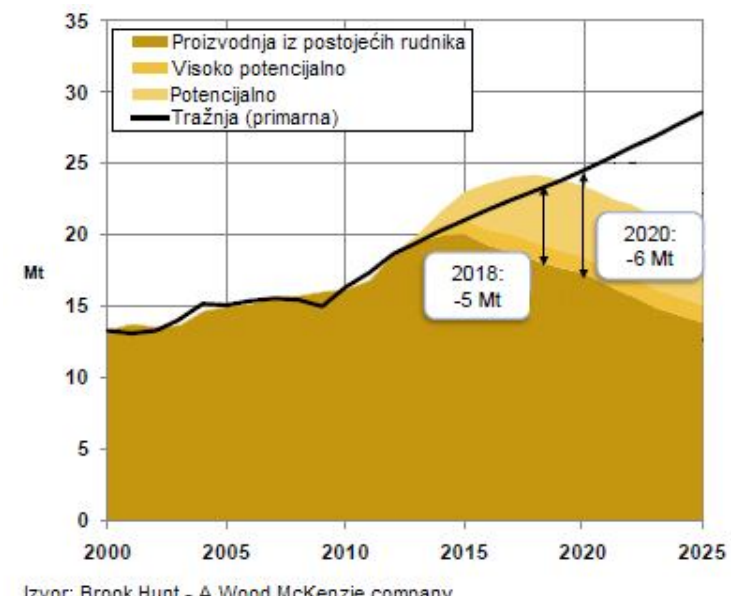

Sl. 4. Trend rudničke proizvodnje bakra u svetu [2]

Takođe je karakteristično da u uslovima kada se sve teže obezbeđuju profiti iz bazne proizvodnje bakra, neminovno dolazi do kompromisa između političkih i geoloških rizika. To znači da će se buduća proizvodnja bakra sve više seliti u zemlje u razvoju sa većim rizikom poslovanja. Takođe je sve više prisutan kompromis između kapitalnih $i$ operativnih troškova. To znači da se $u$ uslovima sve nižeg kvaliteta raspoloživih resursa sve više napušta princip po kome visoki nivo kapitalnih investicija automatski traži niži nivo operativnih troškova.

Zbog toga se u svetu intenzivno radi na razradi novih projekata za eksploataciju i primarnu preradu bakra. Ukupno je trenutno u razradi oko 7.000 projekata. Raspored projekata (za deset glavnih zemalja) je dat na sl. 5 .

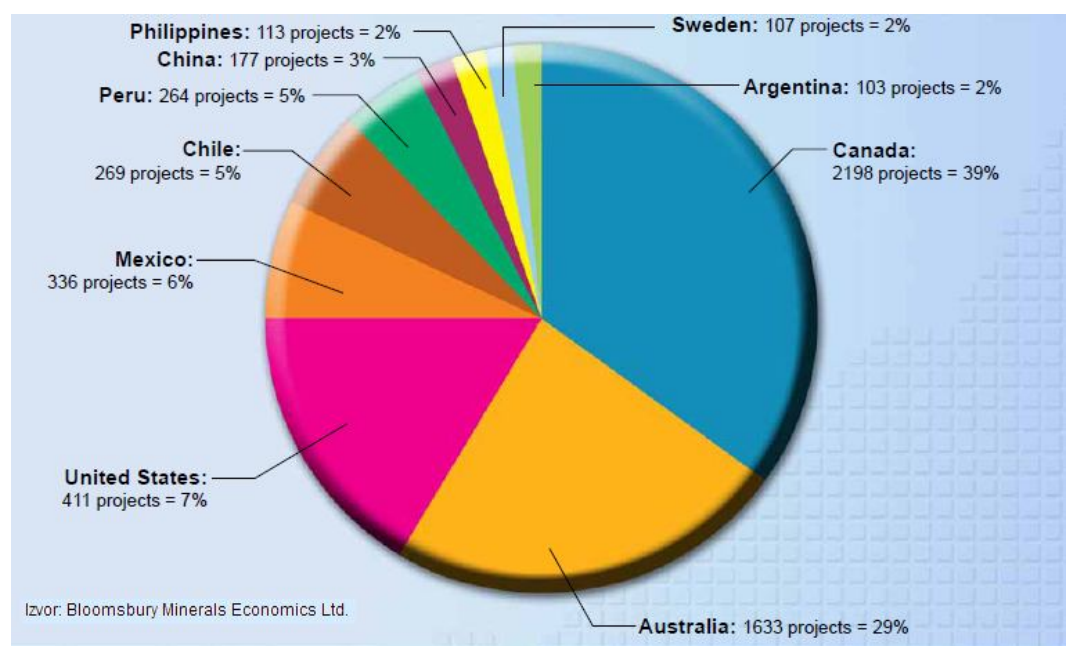

Sl. 5. Raspored projekata za eksploataciju i primarnu preradu bakra u deset glavnih zemalja u svetu [5] 


\section{POLOŽAJ KOMPLEKSA \\ PROIZVODNJE BAKRA SRBIJE NA SVETSKOM TRŽIŠTU}

Kompleks proizvodnje i primarne prerade bakra u Srbiji je dugo godina prisutan na svetskom tržištu. Kao što je ranije u ovom radu pomenuto, sve do kraja sedamdesetih godina prošlog veka, taj položaj je bio vrlo konkurentan. Srbija je u to vreme u ukupnoj proizvodnji bakra u svetu učestvovala sa $2 \%$. Njeni resursi su se isticali po sadržaju bakra i učešću pratećih plemenitih metala. $U$ to vreme kompleks proizvodnje bakra u Srbiji je u svetu imao izuzetan respekt.

Po isteku tog vremena došlo je do sve većeg osiromašenja postojećih rezervi bakra - sve nižeg sadržaja bakra i pratećih metala u eksploatacionim rezervama na sve većim dubinama. Paralelno sa time, uslovi poslovanja u postojećim rudnicima su bivali sve teži. Sve veća količina iskopina po toni proizvedenog bakra i njegova niska cena na svetskom tržištu su sve više pritiskali ekonomiku poslovanja.

\section{Upoređenje resursa za proizvodnju i primarnu preradu bakra Srbije sa resursima u svetu}

Posle skoro osamdeset godina eksploatacije i rada u uslovima relativnog blagostanja, krajem sedamdesetih godina prošlog veka srednji sadržaj bakra u proizvedenoj rudi je sišao ispod $1 \%$ i nastavio permanentan dalji pad. Trenutno se eksploatiše ruda sa srednjim sadržajem bakra na nivou od 0.25 do $0.28 \%$, dok se u planovima za narednih deset godina planira sa srednjim sadržajem bakra od $0.33 \%$. Napred je navedeno da se u razvoju novih projekata $\mathrm{u}$ svetu računa sa srednjim sadržajem od 0.5 do $0.6 \% \mathrm{Cu}$. To znači da su eksploatacioni resursi sa kojima se u Srbiji ulazi u plan za narednih deset godina duplo nižeg kvaliteta od svetskih. Srednji sadržaj bakra u rudi proizvedenoj u Srbiji je dat na sl. 6 .

U svetu se pri projektovanju novih rudnika računa sa količinom od 400 do maksimalno 800 tona iskopina po toni proizvedenog bakra. U Srbiji taj odnos iznosi $1.000 \mathrm{t}$ iskopina po toni bakra. Ako se uporede količine iskopina po toni proizvedenog bakra sa kojima se vrše projekcije buduće

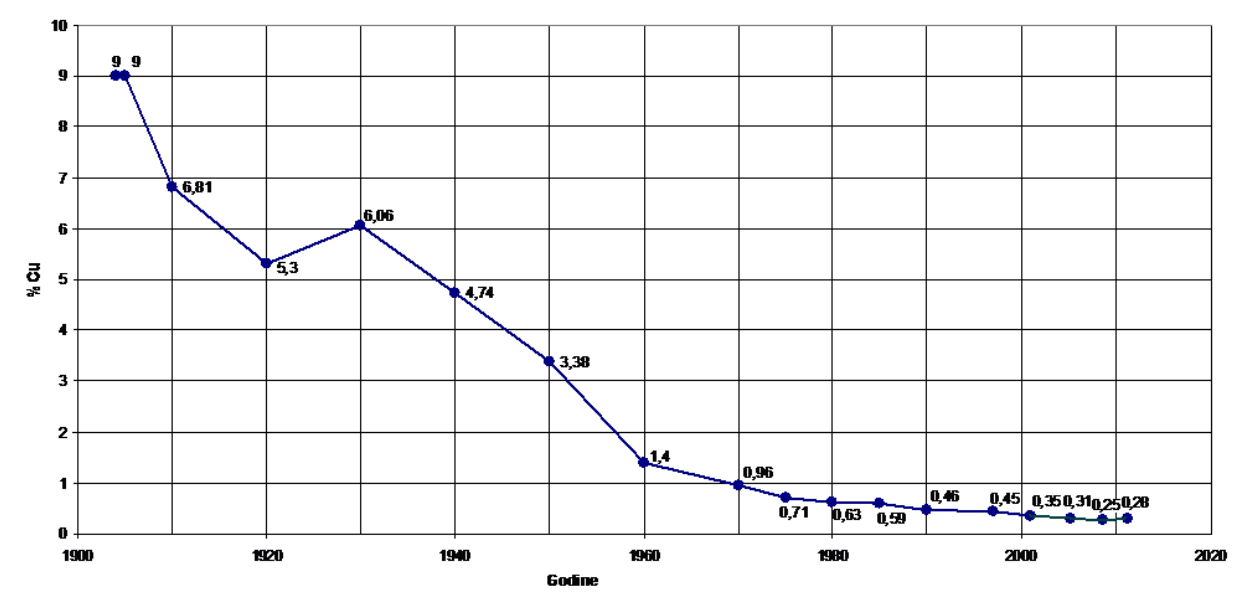

Sl. 6. Srednji sadržaj ostvaren pri eksploataciji rude bakra u Srbiji [10] 
proizvodnje u svetu i u Srbiji, onda se dolazi do zaključka da će se za proizvodnju tone bakra u Srbiji otkopavati od 1.25 do 2.5 puta više iskopina nego u svetu. To znači da eksploatacione rezerve sa kojima Srbija ulazi u program razvoja za narednih deset godina ne mogu da omoguće njen konkurentan položaj $u$ svetu. Dok svet sa pouzdanom dozom sigurnosti vrši projekcije novih rudnika sa cenom koštanja od 5.500 USD/t, u Srbiji je ta projekcija izvršena sa visokih 8.000
USD/t, što značajno povećava rizik budućeg opstanka njenog kompleksa proizvodnje bakra na svetskom tržištu.

\section{Kriva cene koštanja i položaj kompleksa proizvodnje bakra Srbije na njoj}

Da bi neka rudarska kompanija opstala na tržištu (što podrazumeva njenu profitabilnost), mora se pozicionirati tako da bude konkurentna sa drugim rudarskim kompanijama. Upotreba cene metala za

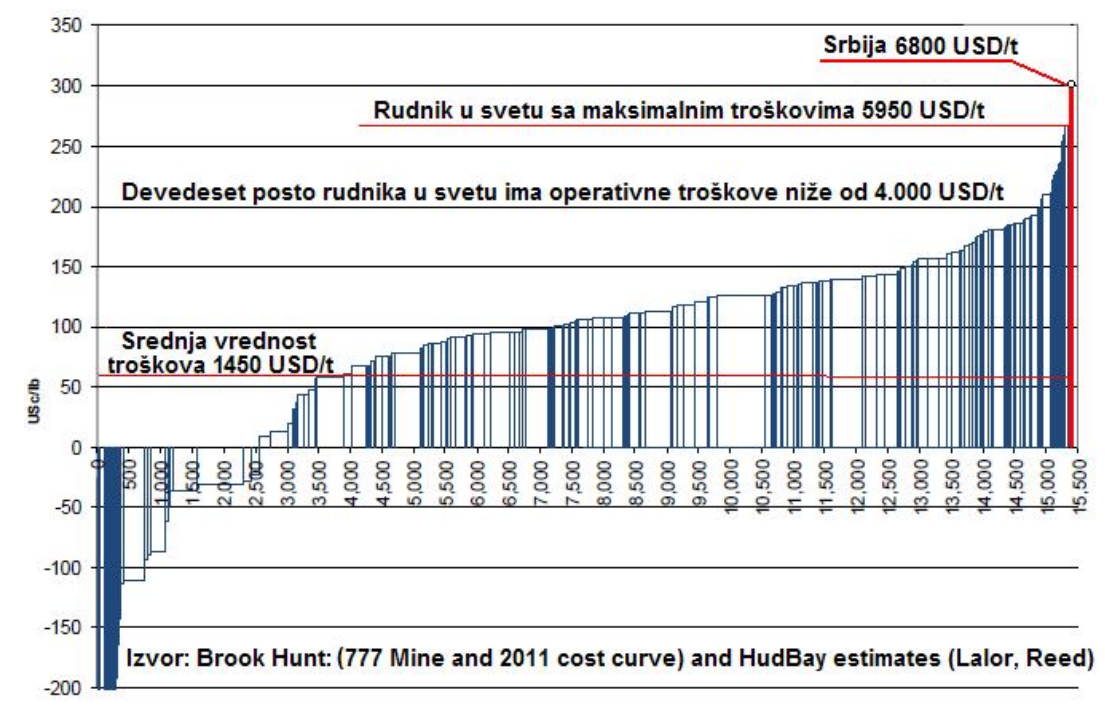

Sl. 7. Položaj kompleksa proizvodnje bakra u Srbiji na krivoj cene koštanja (konkurentnosti) [3]

potrebe planiranja ništa ne govori o konkurentnosti kompanije. Cena metala je neizvesna i uglavnom izvan kontrole proizvođača. Ali troškovi (cena koštanja) su podložni kontroli. Pozicija na krivoj cene koštanja proizvodnje identifikuje konku-rentnost poslovanja i rizik od gubitka, što znači da bi cenu koštanja trebalo smanjivati. Kriva cene koštanja (konkurentnosti) u svetu za 2011. god je prikazana na sl. 7 .

Ključna strategija ili dugoročna vizija za jedan rudnik ili kompaniju je da obezbedi što bolju poziciju na krivoj cene koštanja proizvodnje bakra. Njena primarna strategija treba da bude stalna težnja da se što bolje pozicionira u donjem (levom) delu krive. Sa sl. 7 se vidi da je položaj kompleksa proizvodnje bakra u Srbiji skroz desno na krivoj, sa cenom operativnih troškova od 6.800 USD/t, što mu daje izuzetnu nekonkurentnost na tržištu. Sa sl. 7 se takođe vidi da se $17 \%$ bakra u svetu dobija iz rudnika kao nus-proizvod, koji povećava prihod od osnovnog proizvoda, obično zlata, da je srednja vrednost troškova proizvodnje bakra $1.450 \mathrm{USD} / \mathrm{t}$ a da čak $90 \%$ svetskih kompanija bakra trenutno radi sa cenom koštanja nižom od 4.000 USD/t, dok najviši evidentirani nivo operativnih troškova u svetu iznosi 5.950 USD/t. 


\section{ZAKLJUČAK}

Osnovni problem koji već duže vreme opterećuje položaj kompleksa proizvodnje bakra u Srbiji predstavlja nizak kvalitet eksploatacionih rezervi rude, njihova sve veća dubina $\mathrm{i}$ velika količina iskopina potrebnih za proizvodnju jedne tone bakra. Zbog toga je vrlo nizak stepen njegove konkutentnosti sa ostalim kompanijama u svetu. Sa tog aspekta preporuka je da se učini maksimalan napor za iznalaženje mogućnosti dizanja kvaliteta eksploatacionih rezervi i smanjenje opterećenosti velikim količinama iskopina. To se može postići tako što kompleks proizvodnje bakra u Srbiji treba najozbiljnije razmotriti dosta istraženo i delimično pripremljeno rudno ležišste "Borska Reka", koje je u sagledavanjima strategije razvoja nepravedno zapostavljeno. Kvalitet njegovih ukupnih i overenih rudnih rezervi je na znatno višem nivou od onih koje su obuhvaćene u razvojnim programima i nije opterećeno velikim okoličinama iskopina po toni proizvedenog bakra.

\section{LITERATURA}

[1] AQM Copper Inc, Copper fundamentals, 2010.

[2] Boliden Group, Update and Market Outlook, CMD 2011.

[3] Brook Hunt, 777 Mine and 2011 Cost Curve, 2011.

[4] Indian Bureau of Mines, Market Survey on Copper, Ngapur, 2011.

[5] Interra Resource Intelligence, Copper The New Fundamentals, Mineral Exploration Roundup, 2011.

[6] Mihajlović, B., Istraživanje mogućnosti ekonomične podzemne eksploatacije postojećih rezervi bakra. Doktorska disertacija, Bor, 2003.

[7] Operativna dokumentacija

[8] Page, C., Steffen, O., Adding Shareholder Value By Strategic Mine Planing, SRK, October, 1998.

[9] Rio Tinto, Exploration and Acquisition in the Global Mining Industry, World Mining Investment Congress, London, 2010.

[10] Stamenković, Đ., Borski bakar, prošlost-sadašnjost-budućnost, Bor 1997. 